\section{Yield and Berry Composition of Cold-climate Grape Cultivars and Advanced Selections in lowa Climate}

\author{
James A. Schrader ${ }^{1,2}$, Diana R. Cochran ${ }^{3}$, Paul A. Domoto ${ }^{1}$, \\ and Gail R. Nonnecke ${ }^{1}$
}

AdDitional INDEX wORDs. interspecific hybrids, northern hybrids, viticulture, wine grapes

SUMMARY. Increasing interest in grape (Vitis sp.) and wine production in the upper midwest region of the United States has created a need for science-based information that characterizes the potential of cold-climate cultivars to produce quality grapes with acceptable yields. We evaluated the yield and quality (composition) of grapes from 12 cold-climate, interspecific-hybrid grape cultivars (northern hybrids) grown in a randomized and replicated field plot in central Iowa. The grape trial was planted in 2008 , and crop performance of cultivars was evaluated from 2012 through 2017 (yield) and 2014 through 2017 (berry composition). The trial included two established cultivars, five newer cultivars, and five advanced selections. The established cultivars included in the study as controls were Frontenac and St. Croix. The newer cultivars evaluated in this study were Arandell, Corot Noir, La Crescent, Marquette, and Petit Ami, and the advanced selections were MN 1189, MN 1200, MN 1220, MN 1235, and MN 1258. Yield and productivity were characterized by measuring yield per vine, number of clusters per vine, average cluster weight, and pruning weight. The fruit composition indices were soluble solids concentration (SSC), $\mathrm{pH}$, titratable acidity (TA), and sugar:acid ratio (SSC TA). On the basis of their strong results for both yield and fruit composition measures, 'Marquette', MN 1235, and MN 1220 ranked as the top-performing cultivars in Iowa's climate, followed by Petit Ami and St. Croix. 'Petit Ami' had slightly lower yield consistency and slightly lower results for SSC than did the top performing cultivars, and St. Croix had among the highest and most consistent yields of the trial but showed lower results for SSC and sugar:acid ratio than many of the other cultivars. 'La Crescent' had midrange yields and high SSC, but the high TA of 'La Crescent' fruit resulted in a low sugar:acid ratio at harvest. Two cultivars (MN 1258 and MN 1200) had relatively low yields in Iowa's climate but achieved good results for composition indices. 'Frontenac' had high, consistent yields and achieved high SSC, but the very high TA of 'Frontenac' fruit resulted in a very low sugar:acid ratio compared with most other cultivars. The remaining three cultivars (Corot Noir, MN 1 189, and Arandell) performed poorly in Iowa's climate, showing both low yield and undesirable fruit composition indices compared with the other cultivars in the trial. An itemized summary of the relative ratings for yield and fruit composition is provided to aid growers in selection and management of grape cultivars for use in Iowa and other areas of similar climate.

$\mathrm{T}$ he increasing interest in grape and wine production in colder regions of the United States over the past 3 decades has brought consistent progress in the breeding and selection of cold-tolerant, disease-resistant grape cultivars. Among the most cold-tolerant of these selections is a group commonly referred to as "northern hybrids," which are cultivars based on interspecific hybridization between european common grape (Vitis vinifera) and native grape species such as riverbank grape (Vitis riparia) and fox grape (Vitis labrusca) (Minnesota Grape Growers Association, 2016; Reisch et al., 2002; Smiley et al., 2016). Along with cold tolerance and disease resistance, cultivars suitable for commercial culture in colder regions must produce crops that consistently meet acceptable standards of fruit yield and quality (berry composition). Achieving consistent production of highquality fruit has been identified as one of the most important factors for improving the commercial appeal of cold-climate wine grapes and for making them more competitive with grapes produced in warmer regions (Atucha et al., 2018; Pedneault et al., 2013; Sabbatini and Howell, 2011).

Performance of select northern hybrid cultivars in the cold climates of North Dakota, Vermont, and Wisconsin have been reported as part of the U.S. Department of Agriculture (USDA) National Institute of Food and Agriculture (NIFA), NE-1020 project titled MultiState Evaluation of Winegrape Cultivars and Clones (Atucha et al., 2018; Bradshaw et al., 2018; Hatterman-Valenti et al., 2016). In these studies, achievement of yield and fruit quality goals was inconsistent across years and was limited to a portion of the cultivars evaluated in each trial, results that illustrate the need for continuing research on the selection and evaluation of cold-climate wine grapes. Schrader et al. (2019) characterized the phenology and winterhardiness of 12 northern hybrid cultivars and advanced selections in Iowa's climate during the period from 2011 through 2017. The current study adds to that information by characterizing the yield and fruit composition of grape crops from these same 12 cultivars assessed from 2012 through 2017 in central Iowa.

The objectives of our study were to 1$)$ determine the potential of each cultivar to achieve acceptable yield and fruit quality (composition at harvest) under Iowa's climatic conditions and 2 ) compile and compare results of yield and fruit composition of the 12 cultivars for use as a guide for cultivar selection by growers in Iowa and other areas with similar climate. Results from this trial will provide science-based information that will 1 ) aid in cultivar

\begin{tabular}{llll}
\hline $\begin{array}{l}\text { Units } \\
\begin{array}{l}\text { To convert U.S. to SI, } \\
\text { multiply by }\end{array}\end{array}$ & U.S. unit & SI unit & $\begin{array}{l}\text { To convert SI to U.S., } \\
\text { multiply by }\end{array}$ \\
\hline 0.4047 & acre $(\mathrm{s})$ & $\mathrm{ha}$ & 2.4711 \\
29.5735 & $\mathrm{fl} \mathrm{oz}$ & $\mathrm{mL}$ & 0.0338 \\
0.3048 & $\mathrm{ft}$ & $\mathrm{m}$ & 3.2808 \\
0.4536 & $\mathrm{lb}$ & $\mathrm{kg}$ & 2.2046 \\
1.1209 & $\mathrm{lb} / \mathrm{acre}$ & $\mathrm{kg} \cdot \mathrm{ha}^{-1}$ & 0.8922 \\
28.3495 & $\mathrm{oz}$ & $\mathrm{g}$ & 0.0353 \\
0.7489 & $\mathrm{oz} / \mathrm{gal}$ & $\mathrm{g} / 100 \mathrm{~mL}$ & 1.3353 \\
7.4892 & $\mathrm{oz} / \mathrm{gal}$ & $\mathrm{g} \cdot \mathrm{L}^{-1}$ & 0.1335 \\
$\left({ }^{\circ} \mathrm{F}-32\right) \div 1.8$ & ${ }^{\circ} \mathrm{F}$ & ${ }^{\circ} \mathrm{C}$ & $\left({ }^{\circ} \mathrm{C} \times 1.8\right)+32$
\end{tabular}


selection, 2) deliver insights concerning strengths and weaknesses of each cultivar, and 3 ) help determine the potential of each cultivar for quality grape production in cold climates such as Iowa. To simplify discussion, we have chosen to use the term "cultivar" as a general term to represent both the cultivars and advanced selections in this study, and we use the term "northern hybrids" to represent the 12 cold-climate cultivars that we evaluated. Yield per hectare, yield per vine, cluster number, cluster weight, and pruning weight were used to characterize annual yield and production performance in Iowa's climate. To characterize fruit quality, we measured the three most commonly used variables of fruit composition: SSC, pH, and TA of berries at maximum harvest maturity, and used the SSC and TA measurements to calculate sugar:acid ratio.

\section{Materials and methods}

Nursery-grown plants of 'Arandell', 'Corot Noir', 'Frontenac', 'La Crescent', 'Marquette', MN 1189, MN 1200, MN 1220, MN 1235, MN 1258, 'Petit Ami', and 'St. Croix' were received from Double A Vineyards, Inc. (Fredonia, NY) as part of the NE-1020 project titled "Multi-state Evaluation of Winegrape Cultivars and Clones." Vines were planted on 20 May 2008 (10 cultivars) and 13 May 2009 (two cultivars, Arandell and $\mathrm{MN}$ 1258) at the Iowa State University Received for publication 12 Dec. 2019. Accepted for
publication 15 Jan. 2020.

Published online 13 February 2020.

${ }^{1}$ Department of Horticulture, Iowa State University, Ames, IA 50011

${ }^{2}$ Midwest Grape and Wine Industry Institute, Department of Food Science and Human Nutrition, Iowa State University, Ames, IA 50011

${ }^{3}$ Department of Plant Science and Landscape Architecture, University of Maryland, College Park, MD 20742

This research was supported in part by the U.S. Department of Agriculture/National Institute of Food and Agriculture NE-1020 project "Multi-State Evaluation of Winegrape Cultivars and Clones" and by Iowa State University. We thank Nicholas Howell and the staff of the ISU Horticulture Research Station for their assistance with management of the research plot, and we thank Christopher Currey and Somchai Rice for their helpful critiques of the manuscript.

J.A.S. is the corresponding author. E-mail: jschrade@ iastate.edu.

This is an open access article distributed under the CC BY-NC-ND license (https://creativecommons.org/ licenses/by-nc-nd/4.0/).

https://doi.org/10.21273/HORTTECH04557-19
Horticulture Research Station near Gilbert, IA [lat. $42^{\circ} 6^{\prime} 27^{\prime \prime} \mathrm{N}$, long. $93^{\circ} 35^{\prime} 24^{\prime \prime} \mathrm{W}$, USDA hardiness zone 5a (USDA, 2019)]. Plants were arranged in a randomized complete block design with three-vine panels replicated six times (18 vines per cultivar) and bordered by guard rows and end vines. Soil at the research plot was a well-drained Clarion loam (fine-loamy, mixed, superactive, mesic Type Hapludoll), and no fertilizer was added. Vines of experimental units were trained to a high cordon (single curtain, bilateral cordon), with the trellis wire $6 \mathrm{ft}$ above the ground and vine spacing of $8 \times 10 \mathrm{ft}$. This design accommodated a total of 1344 vines/ha. Pests and diseases were managed according to established protocols of integrated pest management (Hoover et al., 2011). Bird netting was installed each season at $100 \%$ veraison.

Vines were pruned and managed according to the protocols described by Domoto (2014) and Minnesota Grape Growers Association (2016), including compensatory pruning following winters with significant bud injury. Balanced pruning was performed according to the general formula (number of buds retained for first pound of trimmings + number of buds to retain for each additional pound of trimmings up to 4 $\mathrm{lb}$, maximum buds to retain per vine) for example $(20+20,50 \mathrm{max})$. Weight of trimmings was measured in the field by bundling the trimmings and weighing with a handheld digital scale (DHS55; Supco, Allenwood, NJ). For compensatory pruning, the general pruning formula was adjusted based on bud mortality. Bud survival and mortality was measured by collecting two canes per vine that originated from a previous year spur. Canes were held at room temperature $\left(70 \pm 1^{\circ} \mathrm{F}\right)$ for $48 \mathrm{~h}$ to allow oxidation to occur in damaged tissue, after which the first five buds on each cane were assessed by slicing buds in cross-section and visually examining the primary bud for presence of brown discoloration or necrosis as illustrated by Moyer et al. (2011).

Four of the cultivars (La Crescent, Marquette, Petit Ami, and St. Croix) are considered to be moderately productive on secondary buds and usually do not require cluster thinning (Domoto, 2014), therefore pruning was adjusted according to the compensatory equation \{pruning formula $\times[1+(0.4$ yield reduction $\times$ percent bud injury)]\} for primary bud mortality $>20 \%$, otherwise no adjustment. The general pruning formulas for these four cultivars were $20+20,50$ $\max ; 30+10,60 \max ; 20+10,50$ max; and $20+10,50 \mathrm{max}$, respectively (Domoto, 2014). 'Corot Noir' is considered to be moderately productive on secondary buds and normally requires cluster thinning, therefore pruning was adjusted according to the equation \{pruning formula $\times[1+(0.4$ yield reduction $\times$ percent bud injury)]\} for primary bud mortality $>50 \%$, otherwise no adjustment. The general pruning formula for 'Corot Noir' was $20+10$, 50 max (Domoto, 2014). The general pruning formula for 'Frontenac' was $20+20,50 \mathrm{max}$, and 'Frontenac' did not require compensatory pruning during our trial. Specific recommendations for general and compensatory pruning were not available for the remaining six cultivars, so they were managed by the general pruning formula of $20+20,50$ $\max$, and the compensatory equation [pruning formula $\times(1+$ percent bud injury)] for primary bud mortality between $15 \%$ and $50 \%$ and no spring pruning for bud mortality $>50 \%$.

Cultivars were evaluated annually for crop yield and productivity ( 6 years, 2012-17) by measuring yield weight, cluster number, and pruning weight on a per-vine basis, and yield per vine was multiplied by the number of vines per hectare to calculate yield per hectare. Weights for fruit yield and pruning of each vine were measured and recorded in the field, as was cluster number. Average cluster weight was calculated by dividing the yield per vine by the cluster number. Cultivars were evaluated for fruit quality (fruit composition) at harvest maturity (4 years, 2014-17) by measuring $\mathrm{SSC}, \mathrm{pH}$, and $\mathrm{TA}$ of berries. Sugar:acid ratio was calculated for each experimental unit by dividing SSC by TA measured in grams per 100 $\mathrm{mL}$ (Ough and Singleton, 1968). Values for each experimental unit were the means for the three vines in the unit (three-vine panel).

Measures of fruit composition were performed by collecting $>25$ berries from each vine sampled randomly and proportionally from the top, middle, and bottom of clusters. Samples were transported to the laboratory on ice, juiced with a bench-top juicer (Model J8006; Omega, Harrisburg, PA), and pressed through 
cheesecloth. The SSC of grapes was determined by using a temperaturecompensating refractometer (ATAGO USA, Bellevue, WA). From 2011 to 2015, juice $\mathrm{pH}$ was measured with a $\mathrm{pH}$ meter (Orion 2-Star; Thermo Fisher Scientific, Waltham, MA), and a 5-mL juice sample was used to quantify TA by titration with $0.1-\mathrm{N}$ sodium hydroxide $(\mathrm{NaOH})$ to an endpoint of $\mathrm{pH} 8.2$ (Iland, 2004). In 2016 and 2017, a mini-titrator (model HI84532U-01; Hanna Instruments, Woonsocket, RI) was used to measure $\mathrm{pH}$ and $\mathrm{TA}$.

Beginning at $100 \%$ veraison, berries were sampled weekly [morning collections of 100 berries ( 10 berries per vine) from 10 vines of each cultivar and selected randomly and proportionally from the top, middle, and bottom of clusters ] and measured for SSC, pH, and TA. Sampling frequency was increased to daily as readings neared the desired values for harvest. Maximum harvest maturity for each cultivar was judged based on SSC, pH, and TA standards set by Dharmadhikari and Wilker (2001) for white $(21 \%$ to $22 \%$ SSC, $3.2-3.4 \mathrm{pH}$, 7-9 $\left.\mathrm{g} \cdot \mathrm{L}^{-1} \mathrm{TA}\right)$ and red table wines (22\% to $24 \%$ SSC, 3.3-3.5 pH, 6-8 $\mathrm{g} \cdot \mathrm{L}^{-1}$ TA). Because some cultivars failed to reach desired SSC or TA before $\mathrm{pH}$ exceeded optimal values or berries began to lose soundness (e.g., berry dehydration, skin splitting, or bunch rot), maximum harvest maturity for these cultivars was considered to be achieved when $\mathrm{pH}$ in daily samples surpassed 3.55 or when $20 \%$ of berries were no longer sound (Amerine et al., 1980; Atucha and van Zoeren, 2018; Hillin, 2019).

Data analysis. Data were analyzed for main effects, interactions, and means separation across years and cultivars by using statistical software (JMP Pro version 11.0.0; SAS Institute, Cary, NC). Means separation analyses were conducted by using Tukey-Kramer honest significant difference model $(P \leq 0.05)$. Correlation analyses (Pearson correlation) of the relationship between yield and primary bud survival were performed by using the multivariate function of JMP Pro statistical software.

\section{Results and discussion}

For a wine grape cultivar to be acceptable for commercial production in a cool climate such as that of
Iowa, it must produce satisfactory yield and berry quality from year to year despite the challenges from cold winters and short growing seasons. Because numerous factors interact to influence potential profitability of a vineyard (e.g., grape cultivar, fruit quality, sale price, disease and pest control costs, labor costs, mechanization), the minimum sustainable yield needed for vineyard success in the midwestern United States is unknown. However, average yields for commercial vineyards in the midwestern United States have been reported to range from 6725 to $13,450 \mathrm{~kg} \cdot \mathrm{ha}^{-1}$ for wine grapes grown in Indiana, Ohio, and Iowa (Bordelon et al., 1999; Brown et al., 1999; Frank, Rimerman + Co., 2014). In our trial, average yield for northern hybrids varied by year and by cultivar, and there were interactions between the effects of year and cultivar. Results for measures of fruit composition also varied by year and by cultivar, and there were statistically significant interactions but these interactions were subtle.

MAIN EFFECTS OF CULTIVAR AND YEAR. Across the 6 years of evaluation, 'St. Croix', 'Petit Ami', MN 1220, MN 1235, and 'Frontenac' were among the highest yielding cultivars, with each averaging more than $5 \mathrm{~kg}$ of fruit per vine $\left(>7000 \mathrm{~kg} \cdot \mathrm{ha}^{-1}\right)$ in Iowa's climate (Table 1), yields that were within the average range for commercial vineyards in the midwestern United States [6725 to 13,450 $\mathrm{kg} \cdot \mathrm{ha}^{-1}$ (Bordelon et al., 1999; Brown et al., 1999; Frank, Rimerman + Co., 2014)]. Of the 12 cultivars, Arandell, MN 1258, MN 1200, MN 1189, and Corot Noir averaged among the lowest yields $(<3.4 \mathrm{~kg} /$ vine, $<4600$ $\mathrm{kg} \cdot \mathrm{ha}^{-1}$ ), and two cultivars (Marquette and La Crescent) averaged yields that were midrange (5833 and 5739 $\mathrm{kg} \cdot \mathrm{ha}^{-1}$, respectively) between those of the high and low yielding cultivars of the trial.

'Petit Ami', MN 1200, 'St. Croix', 'Marquette', MN 1235, and MN 1220 averaged the highest number of clusters per vine, and 'Arandell' and 'Corot Noir' averaged the lowest number of clusters per vine (Table 1). Although MN 1200 averaged among the highest number of clusters, it had the lowest average cluster weight, which translated to lower yields than most other cultivars across the 6 years. 'Corot Noir' had the highest average cluster weight across years, a result that offset its low number of clusters and gave it a higher yield than some of the other cultivars that had low numbers of clusters. The heavy clusters of 'Corot Noir' also helped it to partially compensate for bud and shoot damage that resulted from its poor cold tolerance in Iowa's climate (Schrader et al., 2019).

Pruning weights often are used as a measurement of vine size or vegetative growth (Lakso, 2013; Minnesota Grape Growers Association, 2016), but in areas of cold climate, pruning weights also are affected by winter bud mortality and compensatory pruning (Dami et al., 2005). Compensatory pruning practices are adjustments made to spring pruning to help compensate for reduced survival of primary buds and help minimize potential crop reduction (Dami et al., 2005; Domoto, 2014; Minnesota Grape Growers Association, 2016). In accordance with recommended practices (Domoto, 2014), cultivars that suffered substantial bud mortality during the coldest winters of our trial were pruned less, and low pruning weights for these cultivars reflect low bud survival rather than low vegetative growth. During some of the winters 'Arandell', MN 1189, 'Corot Noir', and 'Petit Ami' showed low average pruning weights due to low bud survival and compensatory pruning (Schrader et al., 2019), a result that excludes the variable as an indicator of vegetative growth for these cultivars (Table 1). For the remainder of the cultivars, results for average pruning weights indicated that Marquette had the greatest vegetative growth of the northern hybrids in Iowa climate, followed by La Crescent, St. Croix, and Frontenac. On the basis of pruning weight, MN 1258 had the least vegetative growth of the winter-hardy cultivars in the trial, and the rest of the cultivars showed moderate vegetative growth.

For the northern hybrids as a group (across investigated cultivars), yield per vine and number of clusters per vine were greatest in the last 3 years of the trial (2015-17), results that likely reflected a general increase in productivity of vines as they aged (Table 1). Average yield, number of clusters, and cluster weight were among the lowest during 2014 (Table 1), the season that followed the coldest winter of the trial and caused the greatest amount of 
Table 1. Main effects of cultivar and year on yield and berry composition of northern hybrid grape cultivars and advanced selections evaluated in central Iowa from 2012 through 2017 (yield) and from 2014 through 2017 (composition). Values for cultivars are means across years, and values for years are means across the 12 cultivars and selections.

\begin{tabular}{|c|c|c|c|c|c|c|c|c|c|}
\hline \multicolumn{10}{|c|}{ Results for cultivars and selections (across years) } \\
\hline \multicolumn{2}{|c|}{$\begin{array}{l}\text { Cultivars and } \\
\text { selections }^{\mathrm{z}}\end{array}$} & $\begin{array}{l}\text { Yield } \\
(\mathrm{kg} / \\
\text { vine })^{\mathrm{y}}\end{array}$ & $\begin{array}{c}\text { Clusters } \\
\text { (no./ } \\
\text { vine) }\end{array}$ & $\begin{array}{l}\text { Avg cluster wt } \\
(\mathbf{g})^{\mathrm{y}}\end{array}$ & $\begin{array}{c}\text { Pruning } \\
\text { wt } \\
\text { (g/vine })\end{array}$ & $\begin{array}{l}\text { SSC } \\
(\%)^{x}\end{array}$ & $\mathrm{pH}$ & $\begin{array}{c}\text { TA } \\
\left(\mathrm{g} \cdot \mathrm{L}^{-1}\right)^{\mathrm{w}}\end{array}$ & $\begin{array}{c}\text { Sugar:acid } \\
\text { ratio }^{\mathbf{v}}\end{array}$ \\
\hline \multicolumn{10}{|l|}{ Red } \\
\hline \multicolumn{2}{|c|}{ 'Corot Noir' } & $3.35 \mathrm{de}^{\mathrm{u}}$ & $30.6 \mathrm{e}$ & $93.9 \mathrm{a}$ & $322.9 \mathrm{f}$ & $17.9 \mathrm{~d}$ & $3.64 \mathrm{~b}$ & $4.74 \mathrm{~h}$ & $39.0 \mathrm{a}$ \\
\hline \multicolumn{2}{|c|}{ 'Frontenac' } & $5.36 \mathrm{bc}$ & $73.3 \mathrm{bc}$ & $71.9 \mathrm{~b}$ & $643.2 \mathrm{bcd}$ & $24.3 \mathrm{a}$ & $3.36 \mathrm{e}$ & $10.48 \mathrm{a}$ & $23.4 \mathrm{f}$ \\
\hline \multicolumn{2}{|c|}{ MN 1200} & $3.17 \mathrm{e}$ & $95.6 \mathrm{a}$ & $29.8 \mathrm{~d}$ & 574.4 cde & $21.1 \mathrm{~b}$ & $3.57 \mathrm{~b}$ & $6.44 \mathrm{fg}$ & $33.4 \mathrm{bc}$ \\
\hline \multicolumn{2}{|c|}{ MN 1235} & $5.46 \mathrm{ab}$ & $85.8 \mathrm{ab}$ & $63.0 \mathrm{~b}$ & $518.4 \mathrm{de}$ & $21.3 \mathrm{~b}$ & $3.54 \mathrm{bc}$ & $7.26 \mathrm{de}$ & $30.2 \mathrm{de}$ \\
\hline \multicolumn{2}{|c|}{ MN 1258} & $3.03 \mathrm{e}$ & $61.2 \mathrm{~cd}$ & $47.9 \mathrm{c}$ & $304.3 \mathrm{f}$ & $24.0 \mathrm{a}$ & $3.37 \mathrm{e}$ & $8.27 \mathrm{c}$ & $29.4 \mathrm{de}$ \\
\hline \multicolumn{2}{|c|}{ 'St. Croix’ } & $6.52 \mathrm{a}$ & $95.3 \mathrm{a}$ & $70.9 \mathrm{~b}$ & $656.2 \mathrm{bc}$ & $17.3 \mathrm{~d}$ & $3.63 \mathrm{~b}$ & $6.61 \mathrm{ef}$ & $27.0 \mathrm{e}$ \\
\hline \multicolumn{10}{|c|}{ White } \\
\hline \multicolumn{2}{|c|}{$\begin{array}{l}\text { 'Arandell' } \\
\text { 'La Crescent' } \\
\text { MN } 1220 \\
\text { 'Petit Ami' }\end{array}$} & $1.64 \mathrm{f}$ & $31.7 \mathrm{e}$ & $47.2 \mathrm{c}$ & $142.6 \mathrm{~g}$ & $19.8 \mathrm{c}$ & $3.84 \mathrm{a}$ & $5.86 \mathrm{~g}$ & $35.1 \mathrm{~b}$ \\
\hline \multicolumn{10}{|c|}{ Results by year (across cultivars and selections) } \\
\hline Year & $\begin{array}{l}\text { Yield (kg/ } \\
\text { vine) }\end{array}$ & \multicolumn{2}{|c|}{$\begin{array}{c}\text { Clusters (no./ } \\
\text { vine) }\end{array}$} & $\begin{array}{l}\text { Avg cluster wt } \\
(\mathrm{g})\end{array}$ & $\begin{array}{l}\text { runing wt (g/ } \\
\text { vine) }\end{array}$ & SSC (\%) & $\mathrm{pH}$ & $\begin{array}{c}\mathrm{TA} \\
\left(\mathrm{g} \cdot \mathrm{L}^{-1}\right)\end{array}$ & $\begin{array}{l}\text { Sugar:acid } \\
\text { ratio }\end{array}$ \\
\hline 2012 & $3.32 \mathrm{bc}^{\mathrm{u}}$ & \multicolumn{2}{|c|}{$41.5 \mathrm{~d}$} & $76.3 \mathrm{a}$ & $587.0 \mathrm{a}$ & & & & \\
\hline 2013 & $3.89 \mathrm{~b}$ & \multicolumn{2}{|c|}{$59.7 \mathrm{c}$} & $60.7 \mathrm{bc}$ & $408.4 \mathrm{~b}$ & & & & \\
\hline 2014 & $2.57 \mathrm{c}$ & \multicolumn{2}{|c|}{$49.6 \mathrm{~cd}$} & $45.5 \mathrm{~d}$ & $322.7 \mathrm{c}$ & $21.2 \mathrm{ab}$ & $3.46 \mathrm{~b}$ & $7.33 \mathrm{~b}$ & $29.9 \mathrm{a}$ \\
\hline 2015 & $6.09 \mathrm{a}$ & \multicolumn{2}{|c|}{$108.6 \mathrm{a}$} & $55.1 \mathrm{c}$ & $305.1 \mathrm{c}$ & 19.7 b & $3.43 \mathrm{~b}$ & $6.57 c$ & $31.9 \mathrm{a}$ \\
\hline 2016 & $5.13 \mathrm{a}$ & \multicolumn{2}{|c|}{$95.9 \mathrm{ab}$} & $56.5 \mathrm{c}$ & $548.1 \mathrm{ab}$ & $21.4 \mathrm{a}$ & $3.46 \mathrm{~b}$ & $7.19 \mathrm{bc}$ & $31.5 \mathrm{a}$ \\
\hline 2017 & $5.80 \mathrm{a}$ & \multicolumn{2}{|c|}{$90.1 \mathrm{~b}$} & $67.8 \mathrm{~b}$ & $683.8 \mathrm{a}$ & $22.1 \mathrm{a}$ & $3.67 \mathrm{a}$ & $8.08 \mathrm{a}$ & $28.7 \mathrm{a}$ \\
\hline
\end{tabular}

${ }^{\mathrm{z} C u l t i v a r s}$ and selections are listed by wine color.

${ }^{\mathrm{y}} 1 \mathrm{~kg}=2.2046 \mathrm{lb} ; \mathrm{l} \mathrm{g}=0.0353 \mathrm{oz}$.

${ }^{\mathrm{x}}$ Soluble solids concentration.

witratable acidity; $1 \mathrm{~g} \cdot \mathrm{L}^{-1}=0.1335 \mathrm{oz} / \mathrm{gal}$.

vSugar:acid ratio was calculated by dividing SSC by TA in grams per $100 \mathrm{~mL}$ individually for each experimental unit $(\mathrm{Ough}$ and $\mathrm{Singleton}, 1968$ ); $\mathrm{g} / \mathrm{l} 00 \mathrm{~mL}=1.3353 \mathrm{oz} / \mathrm{gal}$. ${ }^{\mathrm{u}}$ Within each section, means within a column followed by the same letter are not different according to Tukey-Kramer honestly significant difference test at $P \leq 0.05$ (for cultivars, $\mathrm{n}=36$ for yield variables and $\mathrm{n}=24$ for composition variables; $\mathrm{n}=72$ for years).

damage to buds (Schrader et al., 2019). Yield, number of clusters, and cluster weight were also low in 2012 (Table 1), a result that was affected by shoot damage from an early spring warming followed by a late spring freeze event (Domoto et al., 2013; Schrader et al., 2019). Although bud damage was substantial during winter 2014-15 (Schrader et al., 2019), average yield and number of clusters per vine were among the highest of the trial in 2015 (Table 1). Pruning weights per vine were lowest during 2014 and 2015, results that reflected the compensatory pruning of vines in response to primary bud mortality during the winters preceding these two seasons (Domoto, 2014). Results for pruning weights were more consistent with expectations during 2012, 2013, 2016, and 2017 because milder winters and lower bud mortality (Schrader et al., 2019) reduced the need for compensatory pruning the following springs (Table 1).
Grape quality is directly related to the composition of the berries when harvested (Bagajewicz et al., 2006). Although specific standards of chemical composition for gauging maturity and quality of cold-climate hybrids have not yet been defined (Riesterer-Loper et al., 2019), general standards of SSC, $\mathrm{pH}$, TA, and SSC:TA ratio (sugar:acid ratio) remain useful for comparing fruit quality of cultivars and for assessing their potential for winemaking (Ahmedullah and Himelrick, 1990; Amerine et al., 1980; Morris et al., 1984). In our trial, general standards of chemical composition for judging maturity and quality of harvested grapes were $21 \%$ to $22 \%$ SSC, 3.2 to $3.4 \mathrm{pH}$, and 7 to $9 \mathrm{~g} \cdot \mathrm{L}^{-1} \mathrm{TA}$ for white grapes and $22 \%$ to $24 \%$ SSC, 3.3 to $3.5 \mathrm{pH}, 6$ to $8 \mathrm{~g} \cdot \mathrm{L}^{-1}$ TA for red grapes (Dharmadhikari and Wilker, 2001).

Results for composition indices of each cultivar were relatively consistent across the 4 years. The subtle interactions that could be resolved were mainly produced by the inconsistent results for MN 1189, which had poor results for berry composition during years when other cultivars had good results (data not shown). We conclude that the inconsistent composition results of MN 1189 were caused by the need to harvest this cultivar early due to bunch rot during most years. The only other interaction that could be resolved was an uncharacteristically high TA result for 'St. Croix' $\left(8.2 \mathrm{~g} \cdot \mathrm{L}^{-1}\right)$ in 2017 , a result that also contributed to an uncharacteristically low sugar:acid ratio (21.4) that year (data not shown).

For the main effects of cultivar, Frontenac, Marquette, MN 1258, and La Crescent averaged the highest SSC at harvest (SSCs $\geq 23.8 \%$ ) of the 12 northern hybrids in Iowa's climate (Table 1). Three other cultivars (MN 1220, MN 1235, and MN 1200) had average SSCs $>21 \%$, results that placed them in or near the target composition standard for SSC. Average SSCs for 
Table 2. Annual yield per vine and per hectare (in parentheses) for 12 northern hybrid grape cultivars and advanced selections evaluated in central Iowa from 2012 through 2017.

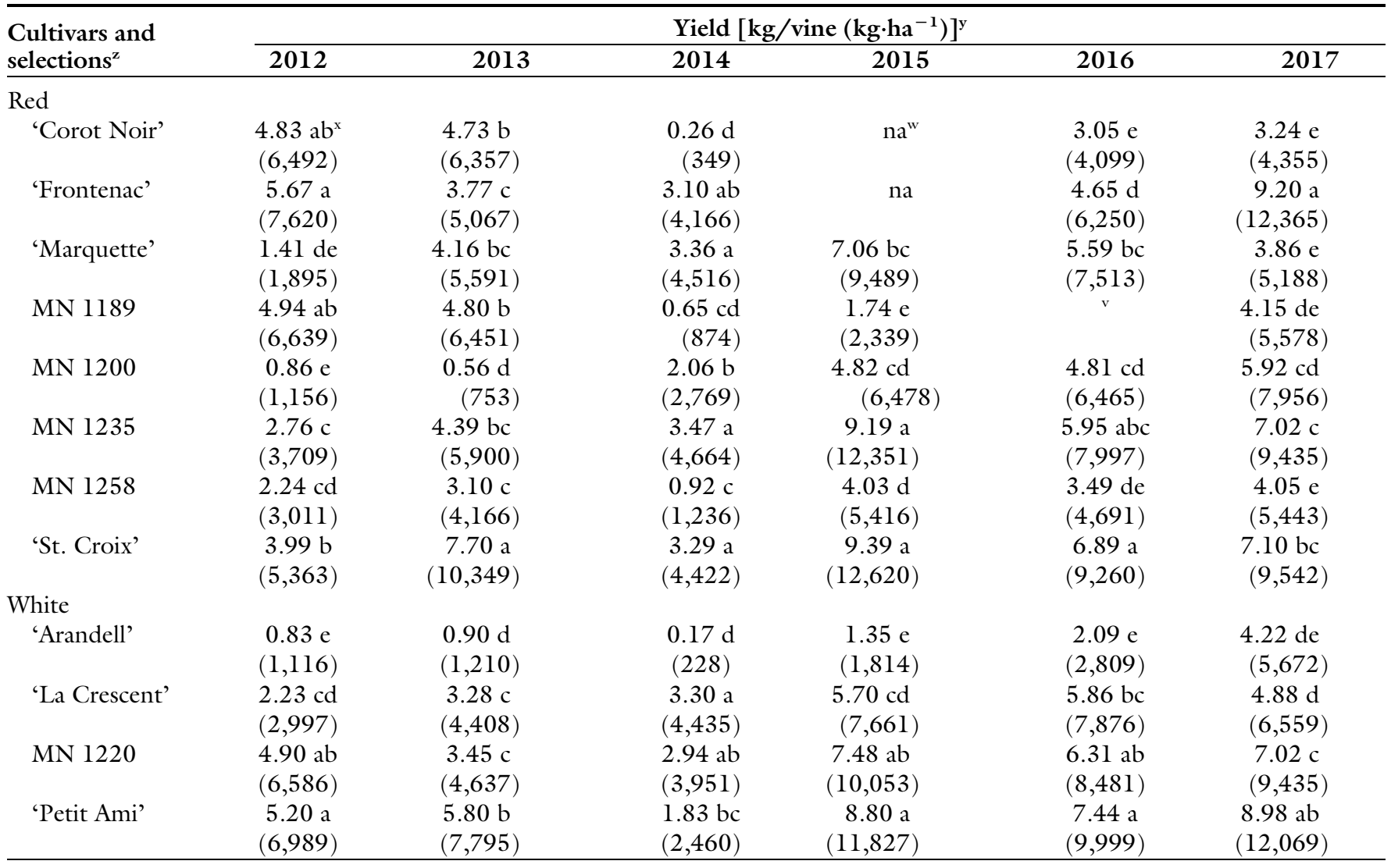

${ }^{\mathrm{z}}$ Cultivars and selections are listed by wine color.

${ }^{\mathrm{y}} 1 \mathrm{~kg}=2.2046 \mathrm{lb} ; \mathrm{l} \mathrm{kg} \cdot \mathrm{ha}^{-1}=0.8922 \mathrm{lb} /$ acre.

${ }^{\mathrm{x}}$ Means within a column followed by the same letter are not different according to Tukey-Kramer honestly significant difference test at $P \leq 0.05$ ( $\mathrm{n}=4$ for results from $2014, \mathrm{n}=$ 6 for results from 2015, 2016, and 2017).

"Not available.

"In 2016, selection MN 1189 exhibited substantial bunch rot, which resulted in nonmarketable fruit.

the other five cultivars (Arandell, Petit Ami, Corot Noir, MN 1189, and St. Croix) were below the desired level based on the general standard (Table 1). The average $\mathrm{pH}$ at harvest was within or near the desired range for each of the cultivars that reached target SSC, and average $\mathrm{pH}$ levels were high for cultivars that averaged SSCs that were below target levels (Table 1 ). Cultivars with average $\mathrm{pH}$ above the target standards (Corot Noir, St. Croix, Arandell, and Petit Ami) reached those levels mainly because we delayed harvest in an effort to achieve target SSC and TA levels. We conclude that the average SSCs and TAs recorded for these cultivars represent the best results achievable under the conditions of our trial because any additional delay in harvest would have resulted in excessively high $\mathrm{pH}$.

Compared with results from trials in other locations that included some of the same cultivars, SSCs achieved in central Iowa were acceptable for wine production. In our trial, SSCs for 'Frontenac', 'Marquette', and 'La Crescent' averaged 24.3\%, $24.0 \%$, and $23.8 \%$, respectively, over 4 consecutive years (Table 1 ). The SSCs reported for 'Frontenac', 'Marquette', and 'La Crescent' grown in southern Wisconsin [same hardiness zone as our trial (USDA Zone 5a)] with the same type of training system (high cordon) averaged $22.1 \%$, $23.9 \%$, and $20.1 \%$, respectively, over 2 consecutive years (Wimmer et al., 2018). Another study in western Vermont (also in USDA Zone 5a) that evaluated 'Marquette' and 'La Crescent' grown on a high-cordon system achieved SSCs of $26.6 \%$ and $26.5 \%$, respectively, during a 1 -year trial (Luby, 2012).

Berries of cold-climate grape hybrids generally contain higher levels of organic acids at harvest than do cultivars of european common grape
(Atucha et al., 2018; Riesterer-Loper et al., 2019). In our trial, average TA of berries at harvest was within or below the target standards recommended by Dharmadhikari and Wilker (2001) for all cultivars except Frontenac, MN 1189, MN 1258, and La Crescent; however, averages for two of these cultivars (La Crescent and MN 1258) were not far from the standard (Table 1). Compared with results for TA of 'Frontenac', 'Marquette', and 'La Crescent' from the Wisconsin trial [2-year average of $13.0,9.9$, and $13.2 \mathrm{~g} \cdot \mathrm{L}^{-1}$, respectively (Wimmer et al., 2018)], results for average TA from our trial were acceptable [TA of $10.48,7.48$, and $9.16 \mathrm{~g} \cdot \mathrm{L}^{-1}$, for 'Frontenac', 'Marquette', and 'La Crescent', respectively (Table 1)]. For two of the cultivars (Corot Noir and Arandell), TA at harvest was low, a result that also coincided with their high $\mathrm{pH}$ at harvest, suggesting that for these 
Table 3. Means for effects of primary bud survival (five range categories of $20 \%$ each) on annual yield per vine for northern hybrid grapes growing in central Iowa recorded across 4 years (2014-17). Range categories of bud survival were used to provide sufficient numbers of units (more than three experimental units per category) for statistical analyses. The absence of a result indicates that there were no experimental units with a bud survival percentage within that category for the specified cultivar or selection.

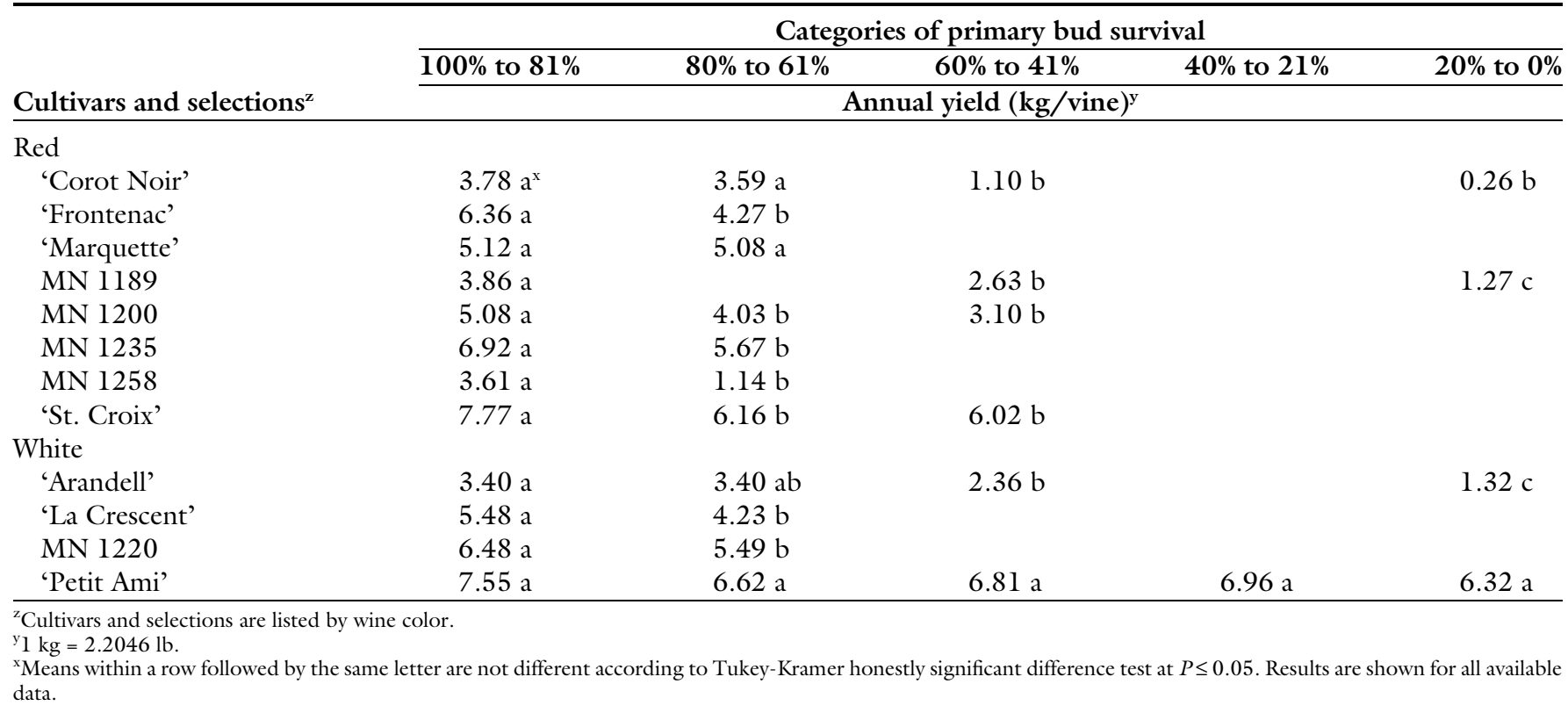

cultivars the risk associated with delaying harvest to raise SSC was unacceptable.

Research assessing correlations between fruit composition and fruit quality rated by expert sensory evaluation has determined that sugar:acid ratio is among the best chemical indices for predicting potential wine quality (Du Plessis and Van Rooyen, 1982; Ough and Singleton, 1968). In general, it is suggested that grapes with sugar-to-acid ratios between 30 and 35 can provide the best balance between sugars and acids for table wines (Cox, 1999). In our trial, seven of the 12 cultivars evaluated had average sugar:acid ratios near or within this range (Table 1). One cultivar (Corot Noir) had an average sugar:acid ratio at harvest that was much higher (39.0) than the preferred range, and four cultivars (Frontenac, MN 1189, St. Croix, and La Crescent) had sugar:acid ratios that were lower than the preferred range $(23.4,20.6,27.0$, and 26.9, respectively). Of the four cultivars that showed low sugar:acid ratio, timing of harvest for two of these cultivars (St. Croix and La Crescent) was near optimal for their performance in central Iowa based on the combination of SSC and $\mathrm{pH}$ values and how these compared with the preferred ranges
(Table 1). One of the other cultivars with low sugar:acid ratio (MN 1189) often was harvested before SSC, $\mathrm{pH}$, and TA reached preferred levels because berries began to lose soundness (berry dehydration, skin splitting, or bunch rot) and harvest could not be delayed. Of the cultivars that reached the target range for SSC but not for TA, Frontenac and MN 1258 likely could have benefited from a longer delay in harvest to decrease TA and increase sugar:acid ratio because their average $\mathrm{pH}$ levels (3.36 and 3.37, respectively) were near the middle of the preferred range and not near the high end of the $\mathrm{pH}$ range preferred for red grapes (3.3-3.5).

On the basis of all the available results for composition variables, two cultivars (Marquette and MN 1220) stand out as fulfilling the most target standards (SSC, TA, and sugar:acid ratio) under conditions of our trial and therefore could be viewed as having the best potential of the 12 cultivars for production of quality wine grapes in Iowa's climate (Table 1). Three other cultivars (MN 1200 , MN 1235, and Petit Ami) fulfilled two of the standards and were near the standard for the third variable, and it seems likely that MN 1258 would have fulfilled all three standards if its average timing of harvest would have been delayed slightly. It is unlikely that the other six cultivars could have fulfilled standards for all three variables under the conditions of our trial, a conclusion indicated by either their high average $\mathrm{pH}$ value at harvest or by the amount that their average for given variables deviated from the standard (Table 1). This, however, does not disqualify them from use in Iowa or similar climates because some of these cultivars possess strengths in areas of yield, hardiness, or vegetative growth that may match with specific production goals.

INTERACTION EFFECTS OF CULTIVAR BY YEAR. Evaluation of the interactions between effects of cultivar and year on grape yield provided insights concerning strengths and weaknesses of the cultivars in Iowa's climate. Consistent with the main effects of year, which showed lower yields for northern hybrids after the coldest winter of the trial [2013-14 (Schrader et al., 2019)], interaction results show that nearly all of the cultivars had numerically lower yields in 2014 than they did in any other year of the trial (Table 2). However, the results also indicated that yields were much lower for some cultivars than for others. Although none of the cultivars produced yields in 2014 that were within the average range for 


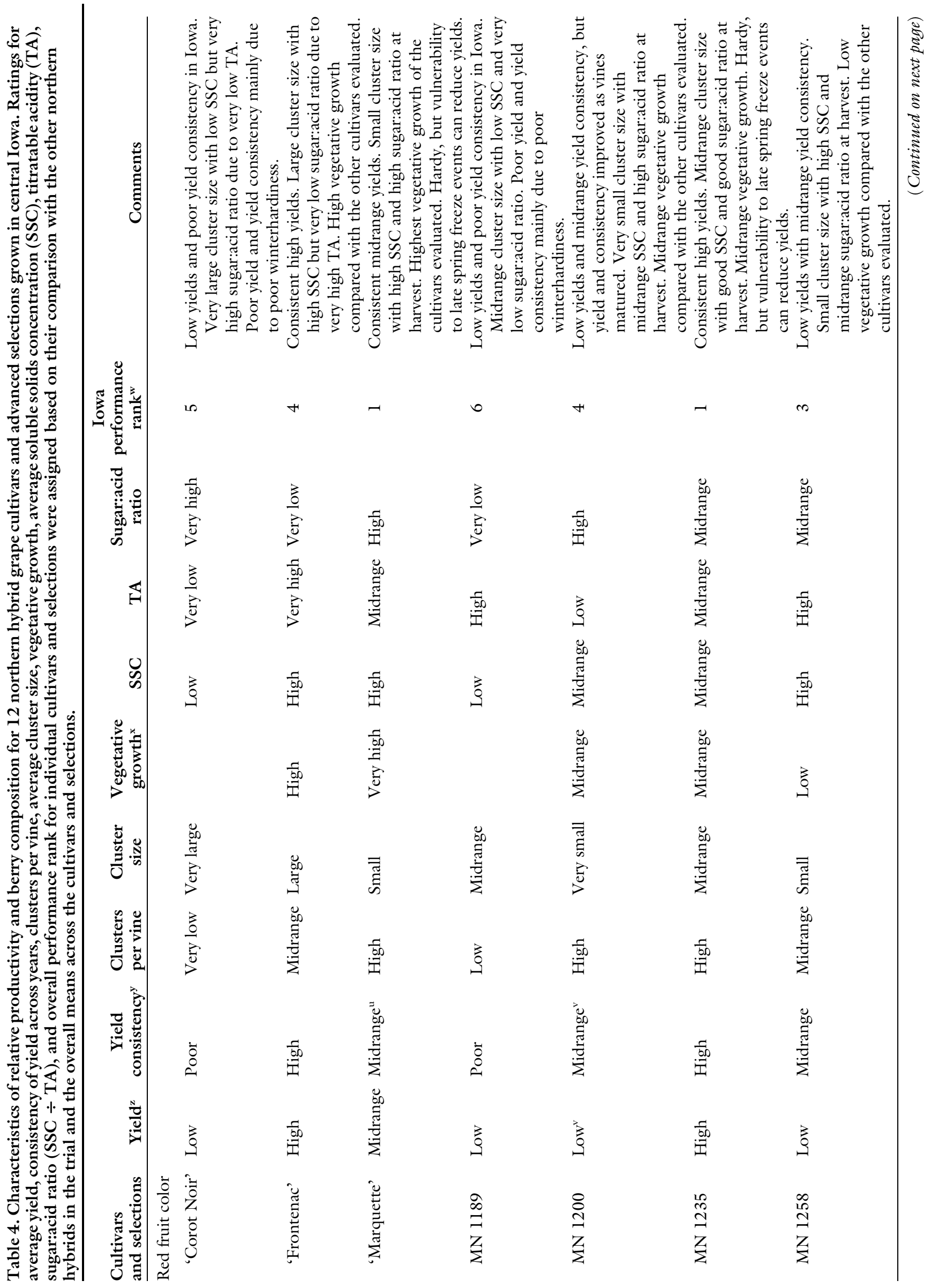

Hortlechnology · April 2020 30(2) 


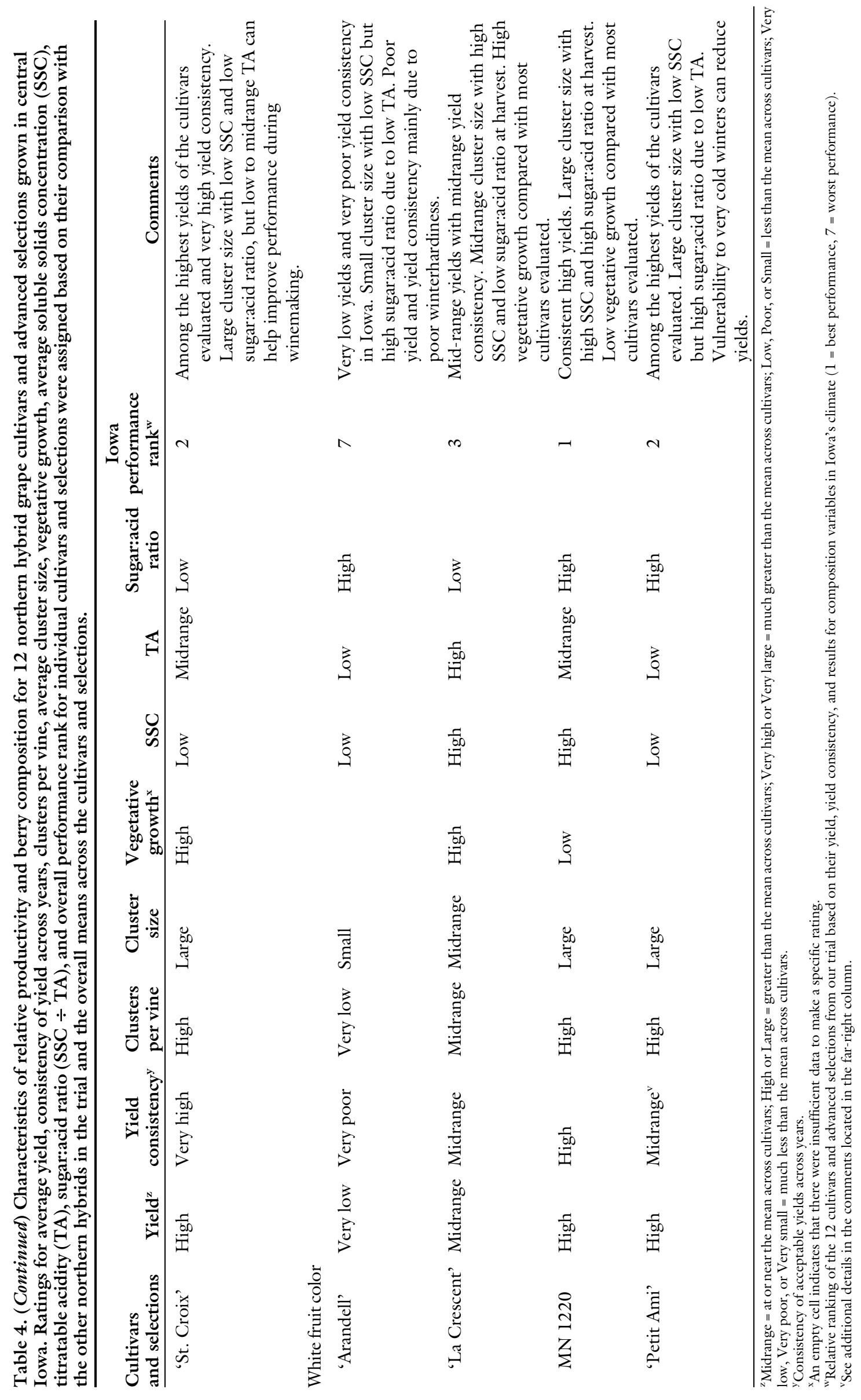


commercial vineyards in the midwestern United States (6725 to 13,450 $\mathrm{kg} \cdot \mathrm{ha}^{-1}$ ), six cultivars (Frontenac, Marquette, MN 1235, St. Croix, La Crescent, and MN 1220) had yields $\left(>2.9 \mathrm{~kg} /\right.$ vine, $\left.>3900 \mathrm{~kg} \cdot \mathrm{ha}^{-1}\right)$ that were higher than those of the other six cultivars (Table 2). Except for 'St. Croix', these were the same cultivars that showed the highest percentage of primary bud survival after Winter 2013-14 (Schrader et al., 2019), results that support the common theory that bud survival has a strong influence on yield and that good bud survival is important for consistent grape production. The cultivars with the lowest percentage bud survival in 2014 [Corot Noir, MN 1189, and Arandell (Schrader et al., 2019)] had extremely low yields that year $[0.26$, 0.65 , and $0.17 \mathrm{~kg} /$ vine, respectively (Table 2)]. After the second coldest winter of the trial [2014-15 (Schrader et al., 2019)], most of the cultivars produced high yields, but two of the cultivars that had the lowest bud survival (MN 1189 and Arandell) also had the lowest yields that year (1.74 and $1.35 \mathrm{~kg} /$ vine, respectively). Although bud survival was relatively low for 'Petit Ami' in 2015 [38.1\% (Schrader et al., 2019)], it was among the highest yielding cultivars that year, results that also were true for Petit Ami in 2017 (Table 2). These results for 'Petit Ami' show that, unlike most of the other cultivars that lacked bud hardiness in Iowa's climate, it can recover strongly after winter damage to primary buds and is able to produce a sizable crop during most years.

The highest yields of the trial were attained in 2015 by 'St. Croix', MN 1235, 'Petit Ami', and MN 1220 $(9.39,9.19,8.80$, and $7.48 \mathrm{~kg} / \mathrm{vine}$, respectively), in 2017 by 'Frontenac' and 'Petit Ami' (9.20 and $8.98 \mathrm{~kg} /$ vine, respectively), and in 2013 by 'St. Croix' $(7.70 \mathrm{~kg} /$ vine). In units per hectare, these results ranged from 10,053 to $12,620 \mathrm{~kg}$ (Table 2 ), values that are near the high end of the average range for commercial vineyards in the midwestern United States (6725 to $\left.13,450 \mathrm{~kg} \cdot \mathrm{ha}^{-1}\right)$. 'St. Croix', MN 1220, MN 1235, and 'Frontenac' had the most consistent acceptable yields across the 6 years of the trial, and 'Petit Ami' was among the highest yielding cultivars each year except for in 2014 (Table 2) when it was affected by cold temperatures during the preceding winter (Schrader et al., 2019). One of the cultivars, MN 1200, had low yields during the first 3 years of the trial and relatively high yields during the last 3 years, indicating that MN 1200 may establish more slowly than most of the northern hybrids in the trial ( $\mathrm{Ta}$ ble 2). As indicated in the main effects of year, yield was low for many of the cultivars in 2012 after an early spring warming and late spring freeze event that damaged shoots (Domoto et al., 2013; Schrader et al., 2019). Cultivars that showed the lowest yields following spring cold damage in 2012 were Arandell, MN 1200, Marquette, La Crescent, MN 1258, and MN 1235 (Table 2).

Correlation Between yield AND PRIMARY BUD SURVIVAL. It is generally accepted that low survival of primary buds through winter can reduce grape yields during the following growing season but that growers can compensate for loss of buds and minimize potential crop reduction by leaving more buds on vines during spring pruning (Dami et al., 2005; Minnesota Grape Growers Association, 2016). Fruitfulness of secondary and tertiary buds is another factor that can affect potential yield following cold damage to primary buds. Secondary buds can produce fruit if the primary bud dies, but the fruitfulness of secondary and tertiary buds varies among cultivars, and yield is generally reduced for all cultivars following substantial damage to primary buds (Dami et al., 2005; Evans, 2000). We quantified the combined effects of bud survival and compensatory pruning on yield of northern hybrids in Iowa climate by analyzing the correlation between primary bud survival and yield and by comparing the yield of each cultivar based on five categories of bud survival, with categories ranging across $20 \%$ points each (bud survival categories of $100 \%$ to $81 \%, 80 \%$ to $61 \%, 60 \%$ to $41 \%, 40 \%$ to $21 \%$, or $20 \%$ to $0 \%$ ). Despite our consistent application of compensatory pruning practices, there was a significant correlation $(r=0.37, P<$ 0.001 ) between primary bud survival and grape yield for northern hybrids as a group. For seven of the 12 cultivars, yield was higher for vines that had $100 \%$ to $81 \%$ primary bud survival than for vines that had $80 \%$ to
$61 \%$ bud survival (Table 3 ). For the five cultivars that did not show a reduction in yield in the $80 \%$ to $61 \%$ bud survival category, three showed a reduction in yield in the next lower category of bud survival $(60 \%$ to 41\%). 'Marquette' and 'Petit Ami' were the only two cultivars in the trial that did not have a reduction in yield for vines in bud survival categories lower than $100 \%$ to $81 \%$. 'Marquette' had no representative vines in the three lowest categories, meaning that its bud hardiness is very good in Iowa's climate, and the small number of 'Marquette' vines that did experience slightly lower bud survival of $80 \%$ to $61 \%$, still had good yields (Table 3). The performance of 'Petit Ami' was an exception to the general trend shown by the other cultivars. Even though 'Petit Ami' had lower bud hardiness than many cultivars in Iowa's climate (Schrader et al., 2019) and had vines with bud survival percentages in all five categories, it showed no significant reduction in yield in any of the categories (Table 3 ). Although we cannot quantify the amount of benefit from compensatory pruning or secondary bud fruitfulness realized by 'Petit Ami', we conclude that it can achieve high yields in Iowa despite the effects of cold damage to primary buds (Tables 2 and 3 ).

Because the performance of 'Petit Ami' was a clear exception to the general trend shown by the rest of the cultivars, an additional correlation analysis was performed for bud survival and yield with the data for Petit Ami removed. On the basis of data from the other 11 cultivars, there was a stronger correlation $(r=0.54, P<$ 0.001 ) between primary bud survival and yield for the northern hybrids as a group. These results support the common theory that good bud survival during the winter dormancy period is a key element for consistent productivity of wine grapes. $\mathrm{Al}$ though compensatory pruning and secondary bud fruitfulness can help offset some of the impacts of low primary bud survival, they do not eliminate those impacts. For most cultivars, low primary bud survival will result in reduced yields.

Performance of Cultivars in IOWA's Climate. Our results demonstrate the yield and berry composition of 12 northern hybrid grape cultivars 
cultured on one training system (high cordon) with vines set at one spacing distance $(8 \times 10 \mathrm{ft})$, a design that supports comparisons among the cultivars and indicates their baseline potential in Iowa's climate. However, it is possible that some or all of these cultivars might perform better under conditions provided by other training systems, spacing specifications, or management practices. Research with cold-climate grapes has shown that the type of training system can affect yield and fruit composition. A study from Wisconsin that included 'Frontenac', 'Marquette', and 'La Crescent' showed that these cultivars can produce substantially higher yields on a Scott Henry training system than on high cordon or vertical shoot positioning systems, and the higher yields can be accomplished with little or no effect on fruit composition (Wimmer et al., 2018). In a study in Vermont, Luby (2012) showed that yield of 'Marquette' and 'La Crescent' can be increased without reducing fruit quality when they are cultured on a Geneva double curtain training system rather than on a single high cordon system. Vine spacing can also have a large impact on grape yield and composition (Dami et al., 2005; Reynolds et al., 2004), a factor that is especially important when comparing results from our trial with results from others. Research also indicates that yield and composition of cold-climate grapes can be improved by vine management practices, such as cluster thinning or leaf pulling (Dami et al., 2006; Riesterer-Loper et al., 2019), practices that were not performed during our trial. Therefore, the potential shown by the cultivars in our trial represents results that could likely be improved upon by implementing specific training systems, vine spacing arrangements, and management practices that can optimize the yield and berry composition of each cultivar in Iowa's climate.

Using all of the available data from our 6-year evaluation of yield and berry composition, we characterized the strengths, weaknesses, and overall performance of the 12 northern hybrid cultivars in Iowa's climate. An itemized summary of the relative ratings for yield, consistency of acceptable yield across years, number of clusters per vine, average cluster size, vegetative growth, average SSC, TA, and sugar:acid ratio of the 12 northern hybrids is provided in Table 4. Also provided are the relative rank of performance of the cultivars based on all measured factors and comments characterizing the performance of each cultivar in Iowa's climate. Four of the cultivars (Frontenac, MN 1235, St. Croix, and MN 1220) had high yields and high consistency of acceptable yields across years, and one cultivar (Petit Ami) had high yields with midrange consistency of acceptable yields across years (Tables 2 and 4). Four red cultivars (Marquette, $\mathrm{MN} 1200, \mathrm{MN} 1235$, and $\mathrm{MN}$ $1258)$ and two white cultivars (MN 1220 and Petit Ami) achieved better average results for composition indices (specifically SSC and sugar:acid ratio) than the other cultivars in the trial. On the basis of all of the variables of yield and composition measured in our evaluation, 'Marquette', $\mathrm{MN} 1235$, and $\mathrm{MN} 1220$ ranked as the top-performing cultivars in Iowa's climate followed by Petit Ami and St. Croix (Tables 1, 2, and 4). 'Petit Ami' had slightly lower yield consistency and slightly lower results for SSC than did the top-performing cultivars, and St. Croix had among the highest and most consistent yields of the trial but showed lower results for SSC and sugar:acid ratio than many of the other cultivars. 'Frontenac', MN 1258, and 'La Crescent' showed good results for either yield or composition measures, but not for both. 'La Crescent' had midrange yields and high SSC, but the high TA of 'La Crescent' fruit resulted in a low sugar:acid ratio. 'Frontenac' had high yields, high yield consistency, and high SSC, but the very high TA of 'Frontenac' berries resulted in a very low sugar:acid ratio compared with most other cultivars. Two cultivars (MN 1258 and MN 1200) had relatively low yields in Iowa's climate but achieved good results for composition indices (Tables $\mathrm{l}$ and 4 ). The remaining three cultivars (Corot Noir, MN 1189, and Arandell) performed poorly in Iowa's climate, showing both poor yield and poor fruit composition compared with the other cultivars in the trial (Tables 1, 2, and 4).

Our results provide information that will aid growers in the selection of cultivars that can best fulfill their goals for production of quality grapes in Iowa and areas with similar climate. The characterization of yield and fruit composition provided by our longterm evaluation of the 12 northern hybrids and the characterization of winterhardiness and phenology provided by Schrader et al. (2019) will be useful to plant breeders for estimating the potential of future hybrid crosses based on these cultivars and advanced selections.

\section{Literature cited}

Ahmedullah, M. and D.G. Himelrick. 1990. Grape management, p. 383-471. In: G.J. Galletta and D.G. Himelrick (eds.). Small fruit crop management. Prentice Hall, Englewood Cliffs, NJ.

Amerine, M.A., H.W. Berg, R.E. Kunkee, C.S. Ough, V.L. Singleton, and A.D. Webb. 1980. The technology of wine making. 4th ed. AVI Publ., Westport, CT.

Atucha, A., J. Hedtcke, and B.A. Workmaster. 2018. Evaluation of coldclimate interspecific hybrid wine grape cultivars for the upper midwest. J. Amer. Pomol. Soc. 72:80-93.

Atucha, A. and J. van Zoeren. 2018. Evaluating cold hardy wine grape maturity. Univ. Wisconsin Ext. Publ. A4154.

Bagajewicz, M., S. Kerr, and M. Frow. 2006. Engineering wine. 7 Aug. 2019. $<$ http://www.ou.edu/class/chedesign/a-design/projects-2006/ FinalReportEngineeringWine.pdf>.

Bordelon, B., C. Janssen, and F. Whitford. 1999. Crop profile for grapes in Indiana. 21 Aug. 2019. <https://ipmdata. i pmcenters.org / d ocuments / cropprofiles/INgrapes.pdf>.

Bradshaw, T.L., L.P. Berkett, S.L. Kingsley-Richards, and J.A. Foster. 2018. Horticultural performance and juice quality of cold-climate grapes in Vermont, U.S.A. Eur. J. Hortic. Sci. 83:42-48.

Brown, M., M. Ellis, D. Doohan, D. Ferree, and R. Williams. 1999. Crop profile for grapes in Ohio. 21 Aug. 2019. <https://ipmdata.ipmcenters.org/ documents/cropprofiles/INgrapes.pdf $>$.

Cox, J. 1999. From vines to wines: The complete guide to growing grapes and making your own wine. 4th ed. Storey Publ., North Adams, MA.

Dami, I., B. Bordelon, D.C. Ferree, M. Brown, M.A. Ellis, R.N. Williams, and D. Deehan. 2005. Midwest grape production guide. Ohio State Univ. Ext. Bul. 919.

Dami, I., D. Ferree, A. Prajitna, and D. Scurlock. 2006. A five-year study on the 
effect of cluster thinning on yield and fruit composition of 'Chambourcin' grapevines. HortScience 41:586-588.

Dharmadhikari, M.R. and K.L. Wilker. 2001. Micro vinification: A practical guide to small scale wine production. Midwest Viticult. Enol. Ctr., Southwest Missouri State Univ., Mountain Grove.

Domoto, P. 2014. Pruning grape vinesEvaluating and adjusting for cold injury. Wine Growers News \#261. Iowa State Univ. Ext., Ames.

Domoto, P.A., G.R. Nonnecke, P. Tabor, and L.B. Riesselman. 2013. Cold hardy wine grape cultivar trial. Iowa State Res. Farm Prog. Rpt. 1915.

Du Plessis, C. and P. Van Rooyen. 1982. Grape maturity and wine quality. S. Afr. J. Enol. Vitic. 3:41-45.

Evans, R.G. 2000. The art of protecting grapevines from low temperature injury. Proc. Amer. Soc. Enol. Viticult. 50th Anniversary Annu. Mtg., Seattle, WA, 1923 June 2000. p. 60-72.

Frank, Rimerman + Co. 2014. The economic impact of Iowa wine and wine grapes. 21 Aug. 2019. <www.traveliowa. com/UserDocs/Iowa_2012_EI_Report_ Final.pdfs.

Hatterman-Valenti, H.M., C.P. Auwarter, and J.E. Stenger. 2016. Evaluation of coldhardy grape cultivars for North Dakota and the North Dakota State University germplasm enhancement project. Acta Hort. 1115:13-22.

Hillin, D. 2019. Grape berry ripening and sampling techniques. 17 Sept. 2019. <https://aggie-horticulture.tamu.edu/ vitwine /2019/07/15/grape-berryripening-and-sampling-techniques $>$.

Hoover, E., S. Wold-Burkness, J. Hilton, D. Mollov, E. Burkness, T. Galvan, P. Hemstad, and W. Hutchison. 2011. Grape IPM guide for Minnesota producers. 8 Jan. 2020 . <https:// conservancy.umn.edu/bitstream/handle/
11299/166875/Grape\%20IPM\%20Guide. pdf? sequence $=1$ \&isAllowed $=y>$.

Iland, P. 2004. Chemical analysis of grapes and wine: Techniques and concepts. Patrick Iland Wine Promotions, Adelaide, Australia.

Lakso, A. 2013. Untangling the concepts of vine size, capacity, crop level, vigor, and vine balance. Grapes 101 in Appellation Cornell, No. 13. 5 Dec. 2019. <https:// grapesandwine.cals.cornell.edu/newsletters/ appellation-cornell/2013-newsletters/issue$13 /$ grapes-101/>.

Luby, C. 2012. The effect of training system and yield on fruit quality of 'Marquette' and 'La Crescent' wine grapes (Vitis spp.) in a Vermont vineyard. J. Amer. Pomol. Soc. 66:34-38.

Minnesota Grape Growers Association. 2016. Growing grapes in Minnesota. 10th ed. 9 Dec. 2019. <https://c.ymcdn. com/sites/ mngrapegrowers.site-ym. com/resource/resmgr/Growing_Grapes_ in_MN_Best_Practices/GGIM_Best_ Practices-book.pdf $>$.

Morris, J.R., C.A. Sims, J.E. Bourque, and J.L. Oakes. 1984. Influence of training system, pruning severity, and spur length on yield and quality of six FrenchAmerican hybrid grape cultivars. Amer. J. Enol. Viticult. 35:23-27.

Moyer, M., L. Mills, G. Hoheisel, and M. Keller. 2011. Assessing and managing cold damage in Washington vineyards. Washington State Univ. Ext. Publ. EM043E.

Ough, C.S. and V.L. Singleton. 1968. Wine quality prediction from juice Brix/ acid ratio and associated compositional changes for White Riesling and Cabernet Sauvignon. Amer. J. Enol. Viticult. 19:129-138.

Pedneault, K., M. Dorais, and P. Angers. 2013. Flavor of cold-hardy grapes: Impact of berry maturity and environmental conditions. J. Agr. Food Chem. 61:10418-10438.

Reisch, B.I., R.M. Pool, D.V. Peterson, M.H. Martens, and T. Henick-Kling. 2002. Wine and juice grape varieties for cool climates. Cornell Univ. Coop. Ext. Bul. 233.

Reynolds, A.G., D.A. Wardle, M.A. Cliff, and M. King. 2004. Impact of training system and vine spacing on vine performance, berry composition, and wine sensory attributes of Riesling. Amer. J. Enol. Viticult. 55:96-103.

Riesterer-Loper, J., B.A. Workmaster, and A. Atucha. 2019. Impact of fruit zone sunlight exposure on ripening profiles of cold climate interspecific hybrid winegrapes. Amer. J. Enol. Viticult. 70:286296.

Sabbatini, P. and G.S. Howell. 2011. Viticultural options to achieve desired grape yield and quality, p. 21-31. In: R.K. Striegler, A. Allen, and J. Harris (eds). Proc. Symp. on Establishing and Managing Vineyards to Meet or Exceed Winery Specifications. Univ. Missouri Ext., Columbia.

Schrader, J.A., D. Cochran, P.A. Domoto, and G.R. Nonnecke. 2019. Phenology and winter hardiness of cold-climate grape cultivars and advanced selections in Iowa climate. HortTechnology 29:906922.

Smiley, L.A., D. Cochran, P. Domoto, G. Nonnecke, and W.W. Miller. 2016. A review of cold climate grape cultivars. Iowa State Univ. Ext. Publ. Hort 3040.

U.S. Department of Agriculture. 2019. USDA plant hardiness zone map. 9 July 2019. <https://planthardiness.ars. Rusda. gov/PHZMWeb/InteractiveMap.aspx>.

Wimmer, M., B.A. Workmaster, and A. Atucha. 2018. Training systems for cold climate interspecific hybrid grape cultivars in northern climate regions. HortTechnology 28:202-211. 